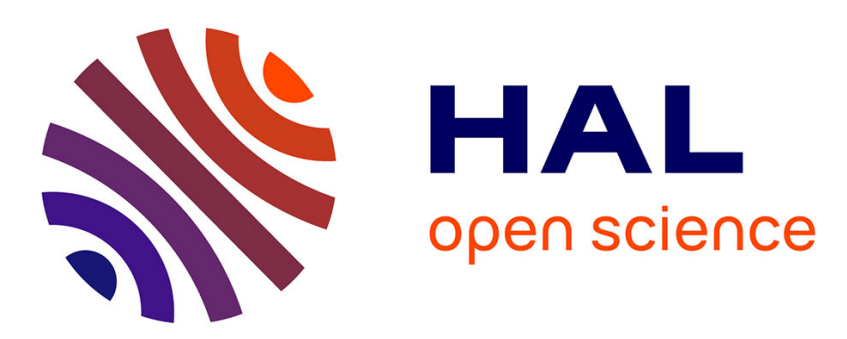

\title{
Democracies, politics and arms supply: A bilateral trade equation
}

Margherita Comola

\section{To cite this version:}

Margherita Comola. Democracies, politics and arms supply: A bilateral trade equation. 2009. halshs00585982

\section{HAL Id: halshs-00585982 \\ https://shs.hal.science/halshs-00585982}

Preprint submitted on 14 Apr 2011

HAL is a multi-disciplinary open access archive for the deposit and dissemination of scientific research documents, whether they are published or not. The documents may come from teaching and research institutions in France or abroad, or from public or private research centers.
L'archive ouverte pluridisciplinaire HAL, est destinée au dépôt et à la diffusion de documents scientifiques de niveau recherche, publiés ou non, émanant des établissements d'enseignement et de recherche français ou étrangers, des laboratoires publics ou privés. 


\section{PARLS SCHOOL OF ECONOMICS}

WORKING PAPER N²008 - 72

Democracies, politics and arms supply:

A bilateral trade equation

Margherita Comola

JEL Codes: F14, D72, F51

Keywords: Arms trade, politics, gravity-type equation

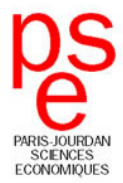




\title{
Democracies, Politics and Arms Supply: A Bilateral Trade Equation
}

\author{
Margherita Comola *
}

December 2009

\begin{abstract}
Throughout the XXth century arms have not only been tradable goods, but also foreign policy instruments. This paper focuses on countries supplying major conventional weapons (MCW), and investigates whether changes in political conditions impact the quantity of MCW supplied to third countries. In particular, I concentrate on democratic exporters and estimate a gravity-type panel TOBIT for the years 1975-2004. Results suggest that the exporter's chief executive being right-wing has a positive and significant impact on MCW exports. This may reflect a general right-wing tendency to support national industry and deregulate heavy industry exports. I also find that higher political competition is associated with higher MCW exports, and that executives serving the last year of their current term tend to increase MCW exports if they cannot be re-elected, and to decrease MCW exports if they run for re-election.
\end{abstract}

Keywords: Arms Trade; Politics; Gravity-type Equation.

JEL codes: F14; D72; F51.

*Paris School of Economics. Email: comola@pse.ens.fr 


\section{Introduction}

The trade in arms has important ethic implications, especially when it involves developing countries: the last 15 years of conflicts have cost Africa a sum that is equivalent to international aid in the same period, and at least $95 \%$ of Africa's most commonly used conflict weapons come from outside the continent (IANSA, Oxfam, and Safeworld, 2007). However, even though during the past decades the public concern on arms trade has increased exponentially, as Hartley and Sandler (1995) point out the topic has not received equal attention by economists and political science scholars. The economic papers on arms trade are not very numerous, and most contributions are theoretical (Peleg, 1977; Levine and Smith, 1995; Levine and Smith, 1997; Levine and Smith, 2000). The few partial-equilibrium empirical papers mostly relate to the demand side (Pearson, 1989; Kollias and Sirakoulis, 2002; Smith and Tasiran, 2005), with only two contributions focused on the supply (Blanton, 2000; Brauer, 2000). In this paper I simultaneously take into account demand and supply side of the arms market to answer a question that relates to economics and politics: whether the internal political conditions in the exporting country influence the amount of arms supplied to third countries. To answer that, a gravity-type panel TOBIT is estimated for the years 19752004. Gravity equations have been extensively used in economics of trade (Bergstrand, 1985; Frankel and Romer, 1999; Egger, 2000; Glick and Rose, 2002; Anderson and Wincoop, 2003). In particular I remand to Summary (1989) who investigates whether international political factors affect US non-arms merchandise exports.

I restrict my attention to major conventional weapons (henceforth MCW), a technologically advanced share of the arms production sector. MCW include aircrafts, armored vehicles, artillery, radar systems, missiles, and ships; it does not include small arms. ${ }^{1}$ All along the XXth century the MCW industry has been highly concentrated: the twenty major MCW producers alone account for $97 \%$ of total worldwide exports for the period 1975-2004. Only five out of these twenty countries have ever experienced an autocratic regime. The core of my analysis focuses on the democracies, which account for more than $65 \%$ of total MCW exports for the period 1975-2004.

The trade in arms is not just business but also a foreign policy issue involving

\footnotetext{
${ }^{1}$ Small arms are excluded because the black share of the market is so big that no reliable transfer dataset is available. Moreover, the small arms industry is less concentrated and nowadays most countries, even among developing ones, produce some amounts of them.
} 
strategic interests (Smith, Humm and Fontanel, 1985; Krause, 1991; Skons, 2000), and international relations during the Cold War have alimented this perception. The market for arms lacks an international regulation, being therefore subject to each country's sovereignty. Arms export licenses are exclusively granted by governmental agencies (mostly inter-ministerial committees) and can be revoked by them. ${ }^{2}$ Even if nowadays licenses for certain destinations are automatically granted, in virtually all exporting countries a relevant share of the arms industry is state property, and arms orders boost the employment of industrial regions (Martin, Hartley and Stafford, 1999). ${ }^{3}$ A welldocumented case of public subsidies are the export credits granted by the UK Export Credit Governmental Department: Martin (1999) concludes that in the UK each job generated by arms export is subsidized by just under 2000 pounds per annum and that a one-third reduction in UK defense exports would save the taxpayer 76 million pounds per annum at 1995 prices. For a detailed overview of the national controls system of the twenty major MCW exporters see the Appendix B.

Given that arms trade is also a foreign policy issue and that governments control arms exports through different channels, my aim is to test how internal politics affects arms export decisions. In Section $4 \mathrm{I}$ first provide evidence that MCW exports of democratic and autocratic regimes differ, and then exclude from the sample major non-democratic producers to concentrate on the political characteristics of democracies only. In the empirical specification, the dependent variable is the amount of MCW transferred and the equation is estimated for years 1975-2004, that is, the core of Cold War and the years right after. The choice of a TOBIT model is consistent with the nature of data.

The results give original insights into arms trade suggesting that, ceteris paribus, the government in power being right-wing significantly increases the quantity of MCW exported. This may reflect a general right-wing tendency to lower trade barriers with its consequences on exports deregulation, or a greater support toward the national ar-

\footnotetext{
${ }^{2}$ Few countries have made their arms licensing regulation more transparent through secondary legislation, while the vast majority of them leave all details to inter-ministerial committees (defense, economic, security ministries and parliament are normally represented). Regulated systems are flexible and subject to varied interpretation and enforcement by the government (see Miller and Brooks, 2001).

${ }^{3}$ The list of Top 100 arms-producing companies (containing information on sales, profit, employment and ownership) is provided on line by the Stockholm International Peace Research Institute (SIPRI).
} 
mament sector in terms of subsidies (perhaps through partly/fully government-funded research) or offset agreements. ${ }^{4}$ I also find that higher political competition in the parliament (as expressed by the Herfindahl index for parties' seats) is associated with higher MCW exports. Finally, data suggests that MCW trade varies during the electoral campaign, perhaps because of the scrutiny of public opinion: executives serving the last year of their current term tend to increase MCW exports if they cannot be re-elected, and to decrease MCW exports if they can run for re-election.

The rest of the paper is organized as follows: in Section 2 the model is briefly described, while Section 3 explains data and variables in use. In Section 4 results are presented, and Section 5 concludes. Tables and figures are presented in the Appendix A. Appendix B contains an overview of arms national export control systems for the twenty major exporters.

\section{The Model}

The panel is unbalanced and evolves along three dimensions: the dependent variable arm $_{i j t}$ is the MCW flow from country $i$ to country $j$ at time $t$. Since the amount of arms traded in a given year equals zero for most observations, I depart from the previous literature using a TOBIT model of the form

$$
\operatorname{arms}_{i j t}= \begin{cases}a r m s_{i j t}^{*} & \text { if } a r m s_{i j t}^{*}>0 \\ 0 & \text { if } a r m s_{i j t}^{*} \leq 0\end{cases}
$$

for

$$
a r m s_{i j t}^{*}=x_{i j t}^{\prime} \beta+\gamma_{i}+\delta_{j}+\phi_{t}+u_{i j t}
$$

where $\gamma_{i}, \delta_{j}$ and $\phi_{t}$ are fixed effects and the covariates $x_{i j t}^{\prime}$ explain both the latent variable arms $_{i j t}^{*}$ and the observed outcome. Fixed effects are a safe choice since $\gamma_{i}$, $\delta_{j}$ and $\phi_{t}$ are likely to be correlated with the regressors. Moreover, they account by

\footnotetext{
${ }^{4}$ Offset agreements are very common counter-trade practices in the defense industry where the supplier (a private company) commits to buy products from the purchasing country. The US Bureau of Industry and Security defines them as "mandatory compensations required by foreign governments when purchasing weapon systems and services".
} 
construction for time-invariant country characteristics and time trends.

I first consider all twenty major exporters as ranked by the Stockholm International Peace Research Institute (SIPRI), which alone account for $97 \%$ of total MCW exports for the period 1975-2004. ${ }^{5}$ These countries -in order of importance- are: the US, the USSR, the UK, France, Russia, China, West Germany (FRG), Czechoslovakia, Italy, Unified Germany (GMY), Netherlands, Sweden, Canada, Poland, Israel, Spain, Ukraine, Switzerland, Brazil, Norway. Out of these twenty exporters, later on I exclude the non-democratic ones: the USSR, China, Czechoslovakia, Poland 1975-1988, and Brazil 1975-1984. The remaining democracies still account for more than $65 \%$ of total MCW exports for the period 1975-2004. On the import side all independent countries recognized by UN are included as potential importers, subject to data availability. ${ }^{6}$

A last issue to be discussed is the timing of the trade. Many categories of arms are grouped under the MCW label and procedures vary from country to country (see Appendix B), however responses to political changes seem to be relatively fast. Even if the production of some arms can take up to a few years, licenses are required not for the negotiation of the contract but for the delivery. ${ }^{7}$ When licenses to delivery arms are granted, they expire in a reasonably short time (within one year for France and Italy). Moreover, licenses can be revoked by the governmental agency under a wide range of circumstances. For all those reasons I stick to the specification in Equation (1) where the response is assumed to be immediate (i.e., within the year): if anything, this is a conservative choice underestimating the size of the overall effect. Specifications

\footnotetext{
${ }^{5}$ Even this way the dependent variable is zero in $91 \%$ of the observations: if I add more exporters the data become intractable.

${ }^{6}$ Importing and exporting countries are classified as in the Correlated of War Project 2005. The only exception is that I code separately Russia and the USSR (USSR data goes until 1991 included, and Russia from 1992 onwards). Whenever data are available I have also included potential importers which have never traded MCW (Andorra, Antigua and Barbuda, Dominica, East Timor, Liechtenstein, Monaco, Nauru, San Marino, Sao Tome e Principe, Santa Lucia, Nauru).

${ }^{7} \mathrm{~A}$ license is required to open negotiations in few specific cases, enumerated in what follows. In Germany an authorization to negotiate is necessary only if intermediaries located in foreign territory are involved. In Italy, companies must be in the national register of arms exporting companies to be able to contract for exports of military items. In the US negotiation is free, except if technical information relevant for national security is revealed in the course of contract. In France licenses are required both for negotiating and delivering arms; in any case, the two procedures are independently conducted and both licenses expire within one year, which is a reasonably short time length.
} 
with the lead dependent variable fit the data considerably worse than the model above (results available upon requests).

\section{Data and Variables Description}

This section illustrates the main features of the data and the variables in use. The regressors' subscripts remind the dimensions of variation ( $i$ for exporter, $j$ for importer, $t$ for time). The time span goes from 1975-2004 to 1980-2004, depending on the specification.

Data on MCW trade come from the Arms Transfers Database by the SIPRI. MCW consist in aircrafts, armored vehicles, artillery, radar systems, missiles, and ships. SIPRI data register MCW transfers to sovereign countries (as well as international organizations, rebel groups, factions and non-governmental armed forces, which appear under a recipients heading different from the country's central government). In order to be registered in the SIPRI dataset weapons must be transferred voluntarily by the supplier and must have a military purpose; time of transfer refers to the moment when delivery is registered. Units of arms are computed according to a trend indicator value system which reflects not economic prices but amounts transferred: the weapons are evaluated for their technical parameters, so that similar weapons have similar scores. ${ }^{8}$ This feature improves the quality of the information in several ways. First, in many cases no reliable data on the economic value of a transfer are available. Second, even if the value of a transfer is known, it is in almost every case the total value of a deal, which may include not only the weapons themselves but also other related items (e.g., spare parts, armament or ammunition, specialized vehicles, software changes to existing systems, or training). Third, even if the value of a transfer is known, important details about the financial arrangements of the transfer (e.g., credit/loan conditions and discounts) are usually not known. On the other side, the SIPRI trend indicator not only registers arms sales, but also other forms of supply including weapons transferred as political aid at a zero price. This trend measure is consistent with the focus

\footnotetext{
${ }^{8}$ For a number of weapon types it is possible to find the actual average unit acquisition price in open sources. Those weapons with a real price are used as reference points, and all other weapons for which a price is not known are assigned a value in an index, reflecting their military resources in relation to core weapons. For a detailed description of the methodology see Hagelin and Wezeman (2005).
} 
of my study: since MCW are also policy instruments, price and market laws would just tell a part of the story. ${ }^{9}$ In all specifications that follow, the dependent variable arm $_{i j t}$ is the SIPRI MCW flow from country $i$ to country $j$ at time $t$ ( 1 unit corresponds to 1 SIPRI point). Only sovereign countries are taken into account, while other entities such as international organizations and non-governmental armed forces are omitted. The SIPRI data are also used to build the variable $M C W$ exports $_{i t}$, which is calculated as the total MCW flow out of the exporter country at time $t$ and is aimed to capture industry fluctuations (1 unit corresponds to 1000 SIPRI points).

Data on democracy come from the Polity IV Project by the Center for Global Policy of George Mason University. I use the composite polity indicator that ranges from -10 (strongly autocratic regime) to +10 (strong democracy): democracy $y_{i t}$ is a dummy equal to one if the exporter's polity indicator is greater than zero. I adopt this dichotomous classification for the sake of simplicity, but it does not affect the results since the distribution is almost bimodal: in $96 \%$ of the cases where democracy $y_{i t}$ equals zero the polity indicator is equal to or smaller than -4, and similarly for $96 \%$ of the cases where democracy $y_{i t}$ equals one the polity indicator is equal to or greater than +6 . In some specification I also control for the importer's democracy score $_{j t}$ (in the original scale from -10 to +10$)$. The transition out of Cold War coincided with the so-called third wave of democratization (Huntington, 1991): between 1987 and 1997, 54 countries went through a process of (full or partial) democratization (Papaioannou and Siourounis, 2008). This is also reflected in the Polity IV data: on the total sample of 168 countries, the median polity score for period $1975-2004$ is 0 , while the median polity score for period 1990-2004 is 5 .

Variables reflecting political conditions come from the World Bank Development Research Group's Database of Political Institutions, DPI2006 (Beck et. al. 2001).

\footnotetext{
${ }^{9}$ The only alternative source of arms trade data is the World Military Expenditure and Arms Transfers (WMEAT) published by the US Department of State, Bureau of Verification and Compliance. The WMEAT measure also covers small weapons and, unlike the SIPRI index, is an economic value measure registering arms bundles sold on the commercial market. As Brzoska (1982) points out, the WMEAT measure has several major problems. First, coverage is worse than in the SIPRI measure. Second, in the many cases where prices are not available, a cost model estimated for US arms industry has been applied to other countries including the USSR, which leads to serious biases as the industrial and employment structure of the two countries are not comparable. Third, the WMEAT measure underestimates the role of western suppliers other than the US and the USSR. Moreover, WMEAT data are not based on open sources of information but on statistics from US intelligence service.
} 
This dataset classifies the chief executives in power as one of the followings, depending on their economic policy: Right (conservative, Christian democratic, or right-wing), Left (communist, socialist, social democratic, or left-wing), Center (for parties that are defined as centrist or when party position can best be described as centrist, e.g. party advocates strengthening private enterprise in a social-liberal context). I use two dummies centrist $t_{i t}$ and left $t_{i t}$ to account for center and left exporter's executives, while the Right dummy is omitted. Just to mention a few examples: all USSR executives are classified as left, while for what regards the US Carter (1977-1981) and Clinton (1993-2001) are classified as left, Regan (1981-1989), G.H.W. Bush (1989-1993) and G.W. Bush (2001-2009) as right. For the United Kingdom, Margaret Thatcher (1979-1990) is classified as right, while Tony Blair (1998-2007) as left. Italian leaders belonging to the Christian Democratic party (Democrazia Cristiana) are classified as centrist for the period 1975-1983 and 1988-1992. In some specification I use the dummy same orientation $_{i j t}$ which equals one if the chief executives in exporter and importer countries are both left-wing, both centrist, or both right-wing. This is to test whether arms trade is dictated by friendship and strategic considerations, as documented by Alesina and Dollar (2000) for international aid. I also include the concentration index

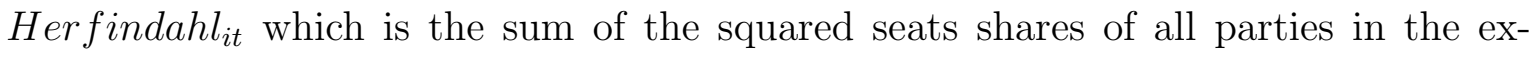
porter's parliament and measures the relative power of the party in power: an higher value of the index means lower political competition. Finally, the dummy end term it equals one if the the exporter's executive is serving the last year of the current term and there is no specific rule limiting re-election. On the other side, end last term it $_{\text {t }}$ equals one if the exporter's executive is serving the last year of the current term and it cannot be (immediately) re-elected. Other time-invariant country characteristics (such as whether the country has common vs. civil law, or a parliamentary vs. presidential system) are taken into account by the fixed effect.

Armed conflicts in the importing country may proxy for the MCW demand side. Data on conflicts come from the Armed Conflict Database provided by the International Peace Research Institute of Oslo (PRIO) and the Uppsala Conflict Data Program (UCDP). This dataset provides detailed information on the type and the severity of conflicts that took place between independent states and/or political factions from 1946 onwards. Conflicts are classified in three categories: interstate armed conflict (which occurs between two or more states), internal armed conflict (which occurs between the government of a state and one or more internal opposition groups without intervention 
from other states) and internationalized internal armed conflict (which occurs between the government of a state and one or more internal opposition groups with intervention from other states). ${ }^{10}$ In my specifications, I include three dummies conflict $A_{j t}$, conflict $B_{j t}$ and conflict $C_{j t}$ which equal one if there is an interstate, internal or internationalized internal conflict in act between the importing country and a third part respectively. When a country has two or more conflicts in the same year, I take the most severe one, according to the following decreasing order of severity: interstate, internationalized internal, internal.

Data for per capita GDP and population, which proxy for countries' supply and demand potentials, come from the Penn World Table Version 6.2 (2007) provided by the Center for International Comparisons of Production, Income and Prices at the University of Pennsylvania. The variables $p g d p_{i t}$ and $p g d p_{j t}$ refer to the countries' per capita GDP (expressed in thousands of US\$), while $p_{0} p_{i t}$ and $p_{0} p_{j t}$ refer to the countries' population (in millions of inhabitants).

In the international market for arms, a formal obstacle to trade is represented by international embargoes, which are relatively frequent and whose effectiveness is highly controversial. There are several types of embargo: international organizations such as the UN, the OECD or the EU impose mandatory or non-mandatory embargoes, and some countries also initiate unilateral export restrictions. I restrict my attention to UN mandatory arms embargoes and retrieve my information combining UN secretariat sources and the dataset on international arms embargoes provided by SIPRI: the

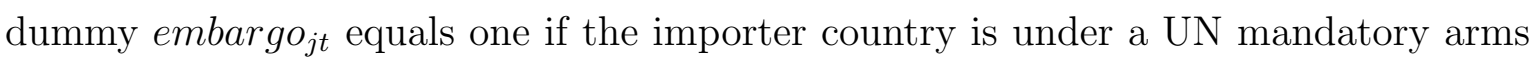
embargo regime at time $t$.

Since geographical and cultural factors correlate with trade, I control for distance is $_{i j}$ which refers to the average distance between the two countries in thousands of kilometers (Gledistch and Ward, 2001). Trade exchanges lead to a diplomatic familiarity and an economic interdependence that may facilitate MCW transfers, and therefore

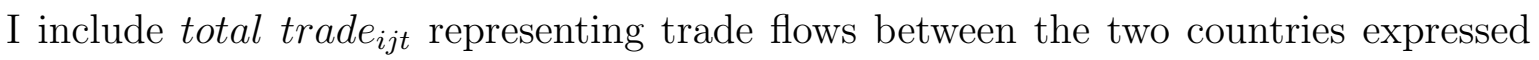
in billions of US\$. These data come from the Expanded Trade and GDP Dataset described in Gledistch (2002).

\footnotetext{
${ }^{10}$ The fourth category of extra-systemic armed conflict (which occurs between a state and a nonstate group outside its own territory) is omitted for having too few positive observations.
} 
All democratic MCW exporters proclaim an ideological concern for human rights and a firm rejection of their abuse. Thus in some specification I also explicitly control for the level of human right violations in the importer country. Data come from the Political Terror Scale dataset (2008) that measures states' human rights record from Amnesty International and the US State Department. I choose the score derived from Amnesty International reports: human rights h $_{j}$ represents human rights violations in act in the importer country on a five-point interval scale, where a higher score indicates more severe violations.

Descriptive statistics are reported in tables 1 and 2.

\section{Results}

\subsection{Democracies vs. Autocracies}

Since my goal is to study the impact of politics on arms exports, I set a first distinction based on the nature of the political regime: whether it is democratic or autocratic. In fact democracies and autocracies may weigh economic and political incentives differently. Moreover, since trade liberalization does not apply to autocratic regimes, there is no a priori reason why left and right autocracies should differ with respect to arms exporting policy. In what follows I provide evidence that democracies and autocracies differ in their MCW exporting behavior.

The results presented in Table 3 are based on the full sample of twenty exporters, where democracies which are $87 \%$ of the sample account for about $65 \%$ of total MCW exports. All results refer to a fixed-effects gravity-type TOBIT where the dependent variable is arms $_{i j t}$. In column (1) a specification with no interactions is presented. The dummy democracyit captures disparities in overall MCW exporting behavior. In addition to the baseline characteristics (per capita GDP and population of exporter and importer), I control for embargoes and conflicts in the importer country, ad for a

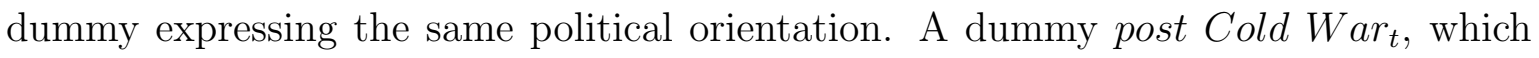
takes value one for years 1990 onwards, is there to capture the sudden worldwide demilitarization which brought a reduction of $40 \%$ in military expenditure and international arms transfers (See Skons, 2000; Dunne et al., 2003). post Cold War and $_{t}$ 
same orientation $_{i j t}$ are also and interacted, in order to take into account the changes in the international scenario: during the Cold War political orientation also reflected bloc division, while after 1989 a major political break and a simultaneous MCW market restructuring took place. In column (2) all regressors of column (1) are interacted with the dummy democracy ${ }_{i t}$. This is a straightforward test to check whether democracies and autocracies differ in any of the previous dimensions.

Results suggest that, once we account for country-specific effects, democracies tend to export more MCW. Also, the interaction terms in column (2) are significant. Exporter's per capita GDP is always positively correlated with MCW exports, but for democracies the effect is much smaller. In contrast, exporter's population is positive for autocracies, but negative for democracies. For what concerns importer's characteristics $p g d p_{j t}$ and $p o p_{j t}$, democracies tend to export MCW to rich countries while autocracies tend to export to poor countries, and importer's population has much more (positive) impact on democracies. Since population and GDP proxy for importer's willingness to pay, this can be interpreted as democratic exporters being more sensitive to pure economic incentives. Embargo policies seem to impact autocracies' exports only. In case of an interstate armed conflict (type A) autocracies tend to export MCW while democracies tend not to. When the conflict is internal (type B) the coefficient is positive and the interaction term is not significant, while in case of internationalized internal conflicts (type $\mathrm{C}$ ) both types of regime tend to decrease MCW exports, but the negative effect is more modest for democracies. The fact that importer and exporter share the same political orientation (both left-wing, or right-wing, or centrist) always has a positive effect, which as expected decreases in magnitude after the Cold War. However, this effect is very little for democracies and much bigger for autocracies. The post Cold War dummy reconfirms the sudden drop in MCW exports after 1989 (Figure 1) and its interaction with democracy ${ }_{i t}$ suggests that the drop was more at the expenses of democracies, who were set on an higher export level before.

\subsection{The Political Conditions of Democratic Exporters}

The previous subsection has shown how democracies and autocracies differ with respect to MCW exporting behavior. I now restrict my attention to the sub sample of democratic exporters (excluding USSR, Czechoslovakia, China, Poland 1950-1988, Brazil 1964-1984) and explore how internal political conditions impact MCW export 
policies.

Results in Table 4 still refer to a fixed-effects gravity-type panel TOBIT where the dependent variable arms $_{i j t}$ is the amount of MCW transferred in a given year. Column (1) contains the baseline specification which covers the entire period 1975-2004. The regressors included are: exporter's political variables (whether the executive is centrist or left-wing, the concentration index Herfindahl $l_{i t}$, and two dummies equal to one if the government is serving the last year of the current term with or without immediate re-election respectively), per capita GDP and population of exporter and importer, embargoes and conflicts in act in the importer country, a dummy for the same political orientation (both left-wing, or right-wing, or centrist), and a dummy for the post Cold

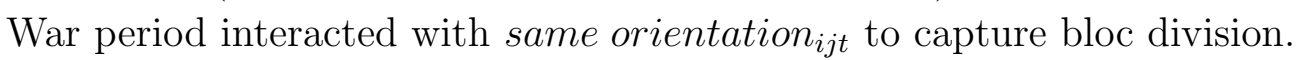

In columns (2) and (3) the regressors are the same as in the baseline, but the exporters' sample is restricted. In column (2) only strongly democratic exporters (polity indicator of 6 and above) are considered. In column (3) I exclude the US (which has always ranked first in MCW exports from the 1950's onwards and which still nowadays exports the majority of the world's weapons).

In column (4) I add trade-related controls: the exporter-specific trend in arms outflows $M C W$ exports $_{i t}$, the distance between the two countries, and the value of the bilateral generic trade flows in that given year. Due to data availability, this specification restricts the time span to 1975-2000.

All democracies proclaim an ideological concern for human rights and democratic governance. In line with previous studies (Blanton, 2000) column (5) controls for the democracy score (in a scale from -10 to +10 ) and human rights violations in the importing country. I also interact the importer's democracy score with the post Cold War dummy: during Cold War the countries in the Eastern bloc were classified as non-democratic, so in principle democracies' reluctance to export to non-democratic countries might have been just due to the fact that many of those countries were part of the Eastern bloc.

Results in Table 4 are consistent across specifications and political variables show interesting patterns. The exporter's chief executive being right-wing has a positive and 
significant impact on MCW exports. This may reflect a general right-wing tendency to lower trade barriers, with its consequences on deregularization of heavy industry exports, or a greater importance of national industry in political agenda, resulting in a higher economic support toward heavy armament sector. With the information we have, there is no way to disentangle those various mechanisms. The concentration

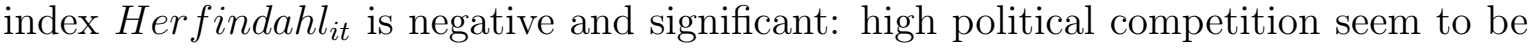
associated with high MCW exports. For what concerns the end of the executive's current term, results are particularly neat: if there is no specific rule limiting re-election

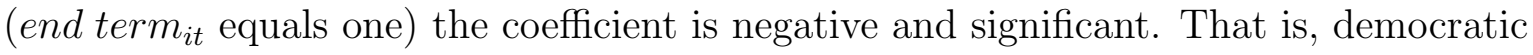
executives decrease their MCW export when running the campaign for re-election. Instead, if the executive cannot be immediately re-elected (end last term lit $_{\text {equals one) }}$ the coefficient is significantly positive and bigger in magnitude: when the mandate is expiring MCW exports increase significantly. This evidence is interesting but hardly surprising, as the public scrutiny of democratic voters is sensitive to arms-related arguments.

All other results go in the expected direction. The exporter having a higher per capita GDP and being less populous increases the quantity of MCW traded, as in Table 3. On the other side, per capita GDP and population of the importer, which may proxy for its likelihood to pay in the MCW open market, are positively significant. UN embargoes pending on the importer country are negative, but only significant in three out of five specifications, in line with the high rate of non-compliance reported by anecdotic and official sources (Amnesty International, IANSA, and Oxfam International, 2006). For what concerns the conflicts in the importer country, internal conflicts (type B) and internal internationalized conflicts (type C) are positive and significant. The only exception is the negative sign of internal internationalized conflicts for highly democratic exporters (column 2). Interstate conflicts (type A) are always negative, but only occasionally significant. The dummy post Cold $W a r_{t}$ is negative itself (apart a small positive effect for the highly democratic exporters), consistently with the general crisis in the industry that led to a reduction of $40 \%$ in military expenditure and international arms transfers (Skons, 2000; Dunne et al., 2003). The coefficient of same orientation $_{i j t}$ is positive and significant, but the negatively-signed interaction with the post Cold War dummy more than compensates the main effect: after the Cold War there is no more space for strategic considerations of political friendships. In column (4) not surprisingly we find that the distance between countries is negatively 
significant and that bilateral trade flows are positively significant. Exporters' market trends $M C W$ exports $_{i t}$ appear negative, which is compatible with the low flexibility of heavy industry supply. For what regards column (5), only the importer's democracy score seems positively significant, while its interaction with the post Cold War dummy is not. Also importer's human rights violations seem not to affect MCW trade.

\section{Conclusions}

All through the XXth century arms have been not only tradable goods, but also foreign policy instruments. Politics can influence arms trade through several channels: regulation is country's sovereignty, export licenses are exclusively granted by governmental agencies, a relevant share of the armament industry is state property, and the arms production sector attracts subsidies and other measures in defense of national industry. This paper focuses on major conventional weapons (MCW) and investigates whether exporter's internal political conditions impact the quantity of MCW supplied to third countries. For this purpose, a gravity-type TOBIT equation is estimated for years 1975-2004. Results suggest that the determinants of MCW supply for autocratic and democratic regimes differ. For what concerns democracies, the government in power being right-wing significantly increases the quantity of $\mathrm{MCW}$ exported. This may reflect a general right-wing tendency to deregulate trade, or a greater support toward the national armament sector. I also find that lower political competition in the parliament (as expressed by the Herfindahl index) associates with lower MCW exports. Finally, data suggests that arms trade is particularly affected during the electoral campaign: democratic executives serving the last year of their current term tend to increase MCW exports if they cannot be immediately re-elected, and to decrease MCW exports if they can run for re-election. The contribution of the paper is to use longitudinally comparative data and a sound quantitative framework to shed light on the political determinants of arms trade along the XXth century. The trade in arms is a debated topic involving political institutions, ethic and economic considerations: a better understanding of its mechanisms is necessary to design an efficient regulation, and this paper is hopefully a step in this direction. 


\section{Appendix A}

Figure 1: Trends in MCW flows, 1975-2004

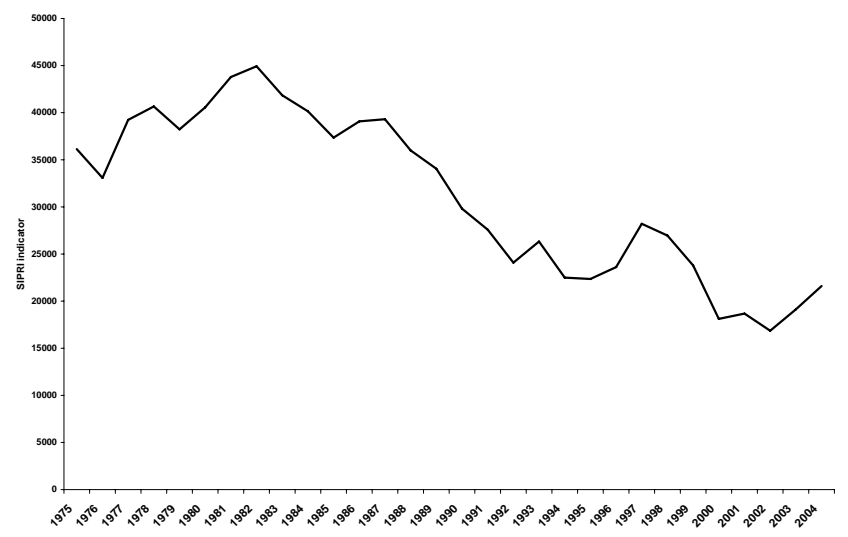

Table 1: Descriptive Statistics, All Exporters

\begin{tabular}{lrrrrr}
\hline \hline variable & $\mathrm{N}$ & mean & $\mathrm{min}$ & $\mathrm{max}$ & $\mathrm{sd}$ \\
\hline arms $_{i j t}$ & 38069 & 9.93 & 0 & 2979 & 80.94 \\
democracy $_{i t}$ & 38069 & 0.87 & 0 & 1 & 0.33 \\
pgdp $_{i t}$ & 38069 & 14.44 & 0.23 & 39.54 & 8.44 \\
pop $_{i t}$ & 38069 & 136.78 & 3.35 & 1294.85 & 282.96 \\
pgdp $_{j t}$ & 38069 & 7.30 & 0.20 & 54.29 & 7.59 \\
pop $_{j t}$ & 38069 & 40.62 & 0.09 & 1294.85 & 144.68 \\
embargo $_{j t}$ & 38069 & 0.01 & 0 & 1 & 0.09 \\
conflict $_{j t}$ & 38069 & 0.02 & 0 & 1 & 0.13 \\
conflict $_{j t}$ & 38069 & 0.11 & 0 & 1 & 0.31 \\
conflict $_{j t}$ & 38069 & 0.02 & 0 & 1 & 0.15 \\
same orientation $_{i j t}$ & 38069 & 0.42 & 0 & 1 & 0.49 \\
post Cold $_{\text {War }}$ & 38069 & 0.55 & 0 & 1 & 0.50 \\
\hline \hline
\end{tabular}


Table 2: Descriptive Statistics, Democratic Exporters

\begin{tabular}{|c|c|c|c|c|c|}
\hline variable & $\mathrm{N}$ & mean & $\min$ & $\max$ & $\mathrm{sd}$ \\
\hline$a_{r m} s_{i j t}$ & 33066 & 10.81 & 0 & 2979 & 84.16 \\
\hline centrist $_{i t}$ & 33066 & 0.10 & 0 & 1 & 0.30 \\
\hline$l e f t_{i t}$ & 33066 & 0.49 & 0 & 1 & 0.50 \\
\hline Herfindahl $l_{i t}$ & 33066 & 0.32 & 0 & 1 & 0.12 \\
\hline end term $_{i t}$ & 33066 & 0.18 & 0 & 1 & 0.39 \\
\hline end last term tit $_{1}$ & 33066 & 0.01 & 0 & 1 & 0.08 \\
\hline$p g d p_{i t}$ & 33066 & 16.15 & 4.39 & 39.54 & 7.67 \\
\hline$p_{p o p}$ & 33066 & 60.47 & 3.35 & 295.41 & 69.53 \\
\hline$p g d p_{j t}$ & 33066 & 7.48 & 0.20 & 54.29 & 7.72 \\
\hline$p o p_{j t}$ & 33066 & 41.63 & 0.09 & 1294.85 & 148.66 \\
\hline$e$ bargo $j t$ & 33066 & 0.01 & 0 & 1 & 0.09 \\
\hline conflict $A_{j t}$ & 33066 & 0.02 & 0 & 1 & 0.13 \\
\hline conflict $B_{j t}$ & 33066 & 0.11 & 0 & 1 & 0.31 \\
\hline conflict $C_{j t}$ & 33066 & 0.02 & 0 & 1 & 0.15 \\
\hline same orientation $_{i j t}$ & 33066 & 0.41 & 0 & 1 & 0.49 \\
\hline post Cold War & 33066 & 0.58 & 0 & 1 & 0.49 \\
\hline$M C W$ exports $_{i t}$ & 33066 & 1.48 & 0 & 16.01 & 3.03 \\
\hline distance $_{i j}$ & 33066 & 6.77 & 0.08 & 19.84 & 4.14 \\
\hline total trade $e_{i j t}$ & 28219 & 2.47 & 0 & 415.26 & 12.39 \\
\hline 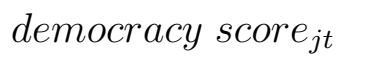 & 29179 & 3.94 & -9 & 10 & 6.94 \\
\hline human rights $_{j t}$ & 21694 & 2.52 & 1 & 5 & 1.10 \\
\hline
\end{tabular}


Table 3: Results, All Exporters

\begin{tabular}{|c|c|c|}
\hline & (1) & (2) \\
\hline democracy ${ }_{i t}$ & $\begin{array}{l}18.259^{* * *} \\
(1.970)\end{array}$ & $\begin{array}{l}141.065^{* * *} \\
(2.145)\end{array}$ \\
\hline$p g d p_{i t}$ & $\begin{array}{l}0.654^{* * *} \\
(0.101)\end{array}$ & $\begin{array}{l}24.094^{* * *} \\
(0.114)\end{array}$ \\
\hline democracy $_{i t} * p g d p_{i t}$ & & $\begin{array}{l}-19.567^{* * *} \\
(0.112)\end{array}$ \\
\hline pop $_{i t}$ & $\begin{array}{l}-0.222^{* * *} \\
(0.005)\end{array}$ & $\begin{array}{l}0.380^{* * *} \\
(0.005)\end{array}$ \\
\hline democracy $_{i t} *$ pop $_{i t}$ & & $\begin{array}{l}-1.503^{* * *} \\
(0.014)\end{array}$ \\
\hline$p g d p_{j t}$ & $\begin{array}{l}6.305^{* * *} \\
(0.118)\end{array}$ & $\begin{array}{l}-40.222^{* * *} \\
(0.135)\end{array}$ \\
\hline democracy $_{i t} * p g d p_{j t}$ & & $\begin{array}{l}46.349^{* * *} \\
(0.134)\end{array}$ \\
\hline $\operatorname{pop}_{j t}$ & $\begin{array}{l}0.636^{* * *} \\
(0.004)\end{array}$ & $\begin{array}{l}0.376^{* * *} \\
(0.005)\end{array}$ \\
\hline democracy $_{i t} *$ pop $_{j t}$ & & $\begin{array}{l}0.249^{* * *} \\
(0.005)\end{array}$ \\
\hline embargo $_{j t}$ & $\begin{array}{l}-12.564^{* *} \\
(5.023)\end{array}$ & $\begin{array}{l}-197.989^{\text {**** }} \\
(8.815)\end{array}$ \\
\hline democracy $_{i t} *$ embargo $_{j t}$ & & $\begin{array}{l}197.976^{* * *} \\
(8.831)\end{array}$ \\
\hline conflict $A_{j t}$ & $\begin{array}{l}0.202 \\
(2.875)\end{array}$ & $\begin{array}{l}67.504^{* * *} \\
(4.481)\end{array}$ \\
\hline democracy $_{i t} *$ conflict $A_{j t}$ & & $\begin{array}{l}-78.365^{* * *} \\
(5.075)\end{array}$ \\
\hline conflict $B_{j t}$ & $\begin{array}{l}48.641^{* * *} \\
(2.207)\end{array}$ & $\begin{array}{l}47.160^{* * *} \\
(3.120)\end{array}$ \\
\hline democracy $_{i t} *$ conflict $B_{j t}$ & & $\begin{array}{l}-4.385 \\
(3.179)\end{array}$ \\
\hline conflict $C_{j t}$ & $\begin{array}{l}-43.765^{* * *} \\
(5.946)\end{array}$ & $\begin{array}{l}-76.764^{* * *} \\
(10.312)\end{array}$ \\
\hline democracy $_{i t} *$ conflict $C_{j t}$ & & $\begin{array}{l}46.807^{* * *} \\
(10.297)\end{array}$ \\
\hline \multicolumn{3}{|c|}{ (to be continued) } \\
\hline
\end{tabular}


Table 3: Results, All Exporters (continued)

\begin{tabular}{|c|c|c|}
\hline & $(1)$ & $(2)$ \\
\hline same orientation $_{i j t}$ & $\begin{array}{l}39.565^{* * *} \\
(1.701)\end{array}$ & $\begin{array}{l}180.998^{* * *} \\
(2.068)\end{array}$ \\
\hline democracy $_{i t} *$ same orientation $_{i j t}$ & & $\begin{array}{l}-158.420^{* * *} \\
(2.070)\end{array}$ \\
\hline post Cold War ${ }_{t}$ & $\begin{array}{l}-47.314^{* * *} \\
(2.325)\end{array}$ & $\begin{array}{l}-64.416^{* * *} \\
(2.535)\end{array}$ \\
\hline democracyit $*$ post Cold War $_{t}$ & & $\begin{array}{l}-26.519^{* * *} \\
(2.514)\end{array}$ \\
\hline same orientation $_{i j t} *$ post Cold War W $_{t}$ & $\begin{array}{l}-28.682^{* * *} \\
(2.091)\end{array}$ & $\begin{array}{l}-27.526^{* * *} \\
(2.305)\end{array}$ \\
\hline Fixed effects for: $i ; j ; t$ & YES & YES \\
\hline Constant & $\begin{array}{l}-1970.405^{\text {*** }} \\
(2.077)\end{array}$ & $\begin{array}{l}-1974.161^{* * *} \\
(2.159)\end{array}$ \\
\hline Sigma & $\begin{array}{l}233.429 * * * \\
(0.654)\end{array}$ & $\begin{array}{l}229.819^{* * *} \\
(0.630)\end{array}$ \\
\hline Observations & 38069 & 38069 \\
\hline Years & $1975-2004$ & $1975-2004$ \\
\hline
\end{tabular}

Robust standard errors in parentheses

*** $\mathrm{p}<0.01,{ }^{* *} \mathrm{p}<0.05,{ }^{*} \mathrm{p}<0.1$ 
Table 4: Results, Democratic Exporters

\begin{tabular}{|c|c|c|c|c|c|}
\hline & $(1)$ & $(2)$ & $(3)$ & $(4)$ & $(5)$ \\
\hline centrist $_{i t}$ & $\begin{array}{l}-13.876^{* * *} \\
(2.227)\end{array}$ & $\begin{array}{l}-11.061^{* * *} \\
(1.135)\end{array}$ & $\begin{array}{l}-18.636^{* * *} \\
(2.274)\end{array}$ & $\begin{array}{l}-27.058^{* * *} \\
(2.320)\end{array}$ & $\begin{array}{l}-15.232^{* * *} \\
(3.116)\end{array}$ \\
\hline left $t_{i t}$ & $\begin{array}{l}-4.191^{* *} \\
(1.673)\end{array}$ & $\begin{array}{l}-1.977^{* *} \\
(0.911)\end{array}$ & $\begin{array}{l}-4.115^{* *} \\
(1.672)\end{array}$ & $\begin{array}{l}-8.150^{* * *} \\
(1.933)\end{array}$ & $\begin{array}{l}-11.471^{* * *} \\
(2.687)\end{array}$ \\
\hline Herfindahl & $\begin{array}{l}-114.511^{* * *} \\
(5.485)\end{array}$ & $\begin{array}{l}-81.681^{* * *} \\
(3.025)\end{array}$ & $\begin{array}{l}-92.647^{* * *} \\
(5.513)\end{array}$ & $\begin{array}{l}-163.170^{* * *} \\
(6.259)\end{array}$ & $\begin{array}{l}-121.064^{* * *} \\
(8.709)\end{array}$ \\
\hline end term ti $_{1}$ & $\begin{array}{l}-13.187^{* * *} \\
(1.664)\end{array}$ & $\begin{array}{l}-7.996^{* * *} \\
(0.857)\end{array}$ & $\begin{array}{l}-13.023^{* * *} \\
(1.668)\end{array}$ & $\begin{array}{l}-13.010^{* * *} \\
(1.849)\end{array}$ & $\begin{array}{l}-13.140^{* * *} \\
(2.440)\end{array}$ \\
\hline end last term it $_{1}$ & $\begin{array}{l}93.826^{* * *} \\
(3.174)\end{array}$ & $\begin{array}{l}35.095^{* * *} \\
(1.636)\end{array}$ & $\begin{array}{l}87.163^{* * *} \\
(3.212)\end{array}$ & $\begin{array}{l}83.103^{* * *} \\
(3.039)\end{array}$ & $\begin{array}{l}93.567^{* * *} \\
(3.616)\end{array}$ \\
\hline$p g d p_{i t}$ & $\begin{array}{l}5.677^{* * *} \\
(0.109)\end{array}$ & $\begin{array}{l}-1.417^{* * *} \\
(0.061)\end{array}$ & $\begin{array}{l}7.070^{* * *} \\
(0.109)\end{array}$ & $\begin{array}{l}3.740^{* * *} \\
(0.142)\end{array}$ & $\begin{array}{l}6.371^{* * *} \\
(0.181)\end{array}$ \\
\hline pop $_{i t}$ & $\begin{array}{l}-0.955^{* * *} \\
(0.014)\end{array}$ & $\begin{array}{l}-4.532^{* * *} \\
(0.016)\end{array}$ & $\begin{array}{l}-1.122^{* * *} \\
(0.014)\end{array}$ & $\begin{array}{l}-0.283^{* * *} \\
(0.019)\end{array}$ & $\begin{array}{l}0.172^{* * *} \\
(0.026)\end{array}$ \\
\hline$p g d p_{j t}$ & $\begin{array}{l}5.332^{* * *} \\
(0.122)\end{array}$ & $\begin{array}{l}3.402^{* * *} \\
(0.063)\end{array}$ & $\begin{array}{l}5.348^{* * *} \\
(0.122)\end{array}$ & $\begin{array}{l}5.139 * * * \\
(0.172)\end{array}$ & $\begin{array}{l}5.980^{* * *} \\
(0.245)\end{array}$ \\
\hline$p p_{j t}$ & $\begin{array}{l}0.640^{* * * *} \\
(0.004)\end{array}$ & $\begin{array}{l}0.252^{* * *} \\
(0.002)\end{array}$ & $\begin{array}{l}0.635^{* * *} \\
(0.004)\end{array}$ & $\begin{array}{l}0.722^{* * *} \\
(0.005)\end{array}$ & $\begin{array}{l}0.750^{* * *} \\
(0.005)\end{array}$ \\
\hline$e$ bargo $j t$ & $\begin{array}{l}-3.510 \\
(5.169)\end{array}$ & $\begin{array}{l}-7.610^{* * *} \\
(2.471)\end{array}$ & $\begin{array}{l}-3.356 \\
(5.174)\end{array}$ & $\begin{array}{l}-22.949^{* * *} \\
(5.547)\end{array}$ & $\begin{array}{l}-16.482^{* *} \\
(6.645)\end{array}$ \\
\hline conflict $A_{j t}$ & $\begin{array}{l}-3.297 \\
(2.634)\end{array}$ & $\begin{array}{l}-2.348 \\
(1.536)\end{array}$ & $\begin{array}{l}-2.104 \\
(2.644)\end{array}$ & $\begin{array}{l}-6.458^{* *} \\
(2.904)\end{array}$ & $\begin{array}{l}-9.807^{* * *} \\
(3.525)\end{array}$ \\
\hline conflict $B_{j t}$ & $\begin{array}{l}43.545^{* * *} \\
(2.283)\end{array}$ & $\begin{array}{l}31.435^{* * *} \\
(1.091)\end{array}$ & $\begin{array}{l}43.307^{* * *} \\
(2.285)\end{array}$ & $\begin{array}{l}45.339^{* * *} \\
(2.441)\end{array}$ & $\begin{array}{l}30.435^{* * *} \\
(3.172)\end{array}$ \\
\hline conflict $C_{j t}$ & $\begin{array}{l}12.038^{* *} \\
(4.698)\end{array}$ & $\begin{array}{l}-6.582^{* * *} \\
(2.179)\end{array}$ & $\begin{array}{l}11.897^{* *} \\
(4.693)\end{array}$ & $\begin{array}{l}87.267^{* * *} \\
(8.353)\end{array}$ & $\begin{array}{l}37.497^{* * *} \\
(11.258)\end{array}$ \\
\hline same orientation $_{i j t}$ & $\begin{array}{l}22.333^{* * *} \\
(1.772)\end{array}$ & $\begin{array}{l}7.999 * * * \\
(0.937)\end{array}$ & $\begin{array}{l}21.640^{* * *} \\
(1.777)\end{array}$ & $\begin{array}{l}17.598^{* * *} \\
(2.004)\end{array}$ & $\begin{array}{l}40.556^{* * *} \\
(2.715)\end{array}$ \\
\hline post Cold War $_{t}$ & $\begin{array}{l}-98.374^{* * *} \\
(2.351)\end{array}$ & $\begin{array}{l}14.631^{* * *} \\
(1.243)\end{array}$ & $\begin{array}{l}-117.732^{\text {*** }} \\
(2.357)\end{array}$ & $\begin{array}{l}-102.309^{* * *} \\
(2.740)\end{array}$ & $\begin{array}{l}-123.937^{* * *} \\
(3.596)\end{array}$ \\
\hline $\begin{array}{l}\text { same orientation }_{\text {ijt }^{*}} \\
\text { post Cold War }\end{array}$ & $\begin{array}{l}-29.760^{* * *} \\
(2.092)\end{array}$ & $\begin{array}{l}-9.028^{* * *} \\
(1.095)\end{array}$ & $\begin{array}{l}-30.370^{* * *} \\
(2.099)\end{array}$ & $\begin{array}{l}-32.983^{* * *} \\
(2.535)\end{array}$ & $\begin{array}{l}-51.151^{* * *} \\
(3.211)\end{array}$ \\
\hline \multicolumn{6}{|c|}{ (to be continued $)$} \\
\hline
\end{tabular}


Table 4: Results, Democratic Exporters (continued)

\begin{tabular}{|c|c|c|c|c|c|}
\hline & (1) & $(2)$ & $(3)$ & (4) & $(5)$ \\
\hline$M C W$ exports $s_{i t}$ & & & & $\begin{array}{l}-21.816^{* * *} \\
(0.375)\end{array}$ & $\begin{array}{l}-19.720^{* * *} \\
(0.556)\end{array}$ \\
\hline distance $_{i j}$ & & & & $\begin{array}{l}-1.021^{* * *} \\
(0.252)\end{array}$ & $\begin{array}{l}-2.641^{* * *} \\
(0.341)\end{array}$ \\
\hline total trade $e_{i j t}$ & & & & $\begin{array}{l}1.990^{* * *} \\
(0.030)\end{array}$ & $\begin{array}{l}2.242^{* * *} \\
(0.040)\end{array}$ \\
\hline 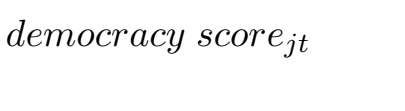 & & & & & $\begin{array}{l}6.026^{* * *} \\
(0.271)\end{array}$ \\
\hline $\begin{array}{l}\text { post Cold } \text { War }_{t} * \\
\text { democracy }_{j t}\end{array}$ & & & & & $\begin{array}{l}-0.416 \\
(0.358)\end{array}$ \\
\hline human rights ${ }_{j t}$ & & & & & $\begin{array}{l}-0.262 \\
(0.936)\end{array}$ \\
\hline Fixed effects for: $i ; j ; t$ & YES & YES & YES & YES & YES \\
\hline Constant & $\begin{array}{l}-1812.277^{* * *} \\
(2.165)\end{array}$ & $\begin{array}{l}-126.549^{* * *} \\
(1.146)\end{array}$ & $\begin{array}{l}-1795.075^{* * *} \\
(2.169)\end{array}$ & $\begin{array}{l}-1889.420^{* * *} \\
(2.411)\end{array}$ & $\begin{array}{l}-2117.776^{* * *} \\
(3.237)\end{array}$ \\
\hline Sigma & $\begin{array}{l}224.475^{* * *} \\
(0.618)\end{array}$ & $\begin{array}{l}104.912^{* * *} \\
(0.375)\end{array}$ & $\begin{array}{l}224.451^{* * *} \\
(0.617)\end{array}$ & $\begin{array}{l}225.674^{* * *} \\
(0.661)\end{array}$ & $\begin{array}{l}240.327^{* * *} \\
(0.845)\end{array}$ \\
\hline Observations & 33066 & 30377 & 32780 & 28219 & 16987 \\
\hline Years & $1975-2004$ & $1975-2004$ & $1975-2004$ & $1975-2000$ & $1980-2000$ \\
\hline
\end{tabular}

Robust standard errors in parentheses

${ }^{* * *} \mathrm{p}<0.01,{ }^{* *} \mathrm{p}<0.05,{ }^{*} \mathrm{p}<0.1$ 


\title{
Appendix B
}

\section{National Export Control Systems ${ }^{11}$}

\author{
CANADA
}

Legislation: Export and Import Permits Act (EIPA) as amended. Licensing Authority: Export Controls Division, Department of Foreign Affairs and International Trade (DFAIT). Consultation Procedures: different branches within DFAIT, the Department of National Defense, Industry Canada and other agencies (such as the Canadian Security Intelligence Service and the Royal Canadian Mounted Police) are asked for specialist advice. End User Requirements:

in most cases one of the following will be required: International Import Certificate; End-use Certificate or Import license; Delivery Verification Certificate; End-use Statement. Types of Licenses: most exports of military goods require a single shipment/single consignee individual license. Some exports of military goods may take place under a multiple shipment/single consignee individual license.

\section{CHINA}

Legislation: Decree of the State Council and the Central Military Commission of the People's Republic of China No. 234, 22 October 1997; Regulations of the People's Republic of China on the Administration of Arms Export, 1 January 1998. Licensing Authority: State Administration of Arms Trade of the People's Republic of China. Consultation Procedures: items of arms export shall be examined and approved by the State Administration of Arms Trade or by the State Administration of Arms Trade jointly with the relevant departments under the State Council and the Central Military Commission.

\section{CZECH REPUBLIC}

Legislation: Act No. 38/1994 of the Legal Code of 15 February 1994. Licensing Authority: Ministry of Industry and Trade. Consultation Procedures: State Security

\footnotetext{
${ }^{11}$ Source: Sipri
} 
Office in the Ministry of Justice, Ministry of Foreign Affairs can request information. End User Requirements: an end user certificate and non-reexport clause should be submitted as part of the license request. Licensing Negotiations: licenses should be applied for after an applicant has received written intent from the buyer to conclude a contract or an invitation to participate in a tender. Revocation Licenses: possible under conditions described in Act No. 38/1994. Types of Licenses: only an individual license is used.

\section{FRANCE}

Legislation: Decree-law of 18 April 1939 creating a regime governing war material, arms, and munitions; Decree no. 55-965 of 16 July 1955 reorganising the Interministerial Committee for the S; Law no. 98-564 of 8 July 1998 with the intent of eliminating antipersonnel mines. Licensing Authority: Interministerial Commission for the Study of Export of War Material (CIEEMG). In the case of dual-use goods: the Service des Titres du Commerce ExtËrieur (SETICE). Consultation Procedures: Autorization for the Exportation of War Material (AEMG) delivered by the Customs general directorate. Possible inspection by the CIEEMG, composed, amongst others, of representatives from the Minister of Defense, the Minister of Economy and Finance, and the Minister of Foreign Affairs. End User Requirements: not directly required. License can be subject to a signed agreement undertaking not to reexport the controlled item. License can also be subject to the proof that the controlled goods are delivered to the authorized recipients. French authorities can request that the controlled item not be reexported in the state in which it was purchased. This is usually relevant in the sale of controlled components or sub-units. Licensing Negotiations: all stages of the contract are controlled, as well as pre-shipment activities. Prospecting, negotiation, and sale require an authorization. Authorizations, when granted, last for one year and can be extended to three years if agreed to by the CIEEMG . Licensing Exemptions: certain exemptions exist for transfer of certain classes of weapons within the European Community and some material depending on its nature and destination e.g. temporary exports, exports made by the Minister of National Defense. Revocation Licenses: possible at any time. Types of Licenses: licenses are usually individual and apply to one exporter for one group of goods and toward one destination. Licenses last for one year. 


\section{GERMANY}

Legislation: War Weapons Control Act, implementing Article 26(2) of the Basic Law; War Weapons Reporting Ordinance of 24 January 1995 (as amended); Foreign Trade and Payments Act of 28 April 1961 (as amended); Foreign Trade and Payments Ordinance of 18 December 1986 (as amended). Licensing Authority: Federal Ministry for Economics in cases of war weapons. In cases of export of other military equipment, the Federal Export Office (an agency of the Federal Ministry of Economics). Consultation Procedures: Federal Foreign Ministry, Ministry of Defence and with other Ministries if appropriate. End User Requirements: an end user document must normally be submitted with the application. There are three types of end user certificate: an official EUC (for government end users); a private EUC (for company or private end users) and an International Import Certificate (IIC). Licensing Negotiations: no authorization required for negotiating a contract; a special license is required for deals by intermediaries regarding the procurement of war weapons which are located abroad and are to be delivered to the foreign customer without encountering German territory. Licensing Exemptions: in certain cases, such as insignificant parts of firearms, military equipment can be exported under a general license. Revocation Licenses: possible only under narrow legal conditions such as a false statement in a license application. Types of Licenses: there is no distinction between licenses based on destination; exports within the framework of an intergovernmental cooperation project are covered by a general license.

\section{ITALY}

Legislation: Law No. 185/90, 9 July 1990 (New Rules for the Control of Export, Import and Transit of Conventional Weapons). Licensing Authority: Ministry for Foreign Affairs. Consultation Procedures: Ministry of Defence, Ministry of Industry, Ministry of Foreign Trade, Ministry of Finance (Customs), Treasury. End User Requirements: an end-user certificate is required for all destinations. However, the certificate can take different forms depending on the destination. Import certificates and delivery verification certificates are not verified if provided by the governmental authorities of the importing countries. The end-user certificate also includes a no reexport statement regarded as a contractual obligation between Italy and the importing country. Licensing Negotiations: license applications are examined on a case by case basis. Prior authorisation is required before a contract is signed. Licensing Ex- 
emptions: the 1990 Law No. 185/90 does not apply to the following: a) temporary exports directly effected by, or on behalf of the Central Government, to implement its own arms and equipment programmes for the armed forces and police; b) exports or concessions between governments for the purposes of military aid, under the terms of international agreements; c) the transit of armaments and equipment to meet the needs of allied countries, as defined in the Convention on the Status of NATO Forces, provided that waivers to Articles VI, XI, XII, XIII and XIV of the Convention between the States signatories to the North Atlantic Treaty are not invoked for any reason whatsoever. Revocation Licenses: licenses can be revoked at any time. Types of Licenses: a national register of companies operating in the field of planning, manufacture, import, export, maintenance and servicing of military products is maintained. Only companies in the register may receive permission to negotiate contracts for exports of military list items. Only individual licenses are used. Special conditions can be attached to an individual license (normally valid for 1 year) on a case-by-case basis.

\section{NETHERLANDS}

Legislation: Import and Export Law (1962); Decree on the Export of Strategic Goods (1963). Related laws and decrees: the Decree on the Delivery of Declaration of Strategic Goods forms the basis for International Import Certificates (IIC's) and Delivery Verification Certificates; the Decree on Financial Transactions for Strategic Goods demands that a license is required in each case a Dutch legal or natural person is financially involved in the trade of strategic goods that are in transit or otherwise outside the European Union; the Law Governing Economic Violations provides for the possibility of sanctions in cases of breaches of the aforementioned regulations and sets the framework for control and enforceability; the Sanctions Law provides for the possibility to implement recommendations, resolutions or agreements of international organizations (such as the UN) on international trade sanctions for military or other goods. Licensing Authority: applications for export licenses are submitted to the Import and Export Licensing Branch of the Ministry of Finance. Export licenses are issued by the Ministry of Economic Affairs on the basis of information contained in the contract, in the International Import Certificate, and/or in the end-user statement. Consultation Procedures: if the application involves inter alia military equipment which is also in use by or specially developed and designed for the Dutch armed forces, the Ministry of Foreign Affairs consults with the Ministry of Defense on the possible classification 
aspects. Subsequently, the Minister for Foreign Affairs submits his advice, which plays an essential role in the decision making process. If there are no objections with regard to the proposed export, the export license is issued by the Ministry of Economic Affairs. End User Requirements: in principle, all military shipments require an International Import Certificate or an end-user certificate. Licensing Negotiations: the formal application procedure requires the submission of a signed contract. There is no official government authority required to enter into contract negotiations or to sign contracts with foreign customers. Licensing Exemptions: no license is required for exports to Belgium and Luxembourg. Revocation Licenses: the Import and Export Law provides for two possibilities to revoke export licenses: if the information provided by the licensee in order to receive the license appears to be inaccurate or incomplete; or if there is a very urgent or serious reason, for example war or the threat of war. Types of Licenses: there are two types of license: an individual license for a shipment to an end-user in one country only, for one or for different kinds of goods (value and quantity of the shipment have to be indicated at the time of application); a global license, which is a more flexible means of licensing and allows multiple shipments of a range of goods to several destinations (e.g. issued in case of a project in one or more countries).

\section{NORWAY}

Legislation: Law of 18 December 1987 no. 93 on Control over the Export of Strategic Goods, Services and Technology; Ministry for Foreign Affairs Decree of 10 January 1989 to implement export regulations for strategic goods, services and technology. Licensing Authority: Section for Export Control, Ministry of Foreign Affairs. Consultation Procedures: The Ministry for Foreign Affairs may consult the Ministry of Defense in cases where an application to export has particularly important implications to national defense or to participation in international defense industrial cooperation. The Ministry for Foreign Affairs may consult the Defense Research Institute within the Ministry of Defense in cases where information is required on technical aspects of the use of particular items. The Ministry for Foreign Affairs may consult the Ministry of Economy in cases where an application to export has important implications for Norwegian economic interests. End User Requirements: The Ministry of Foreign Affairs may require end-user statements in connection with the export of products included in lists I and II and with the export of technology or provision of services in connection with all such products. Licensing Negotiations: no authorization required for 
seller/buyer negotiations. Licensing Exemptions: precursors to chemical weapons if the substance in question makes up less than 10 percent of a mixture or forms a normal component of consumer goods packaged for personal use, recovery and oil rig equipment that is to be used in emergency assistance actions, arms that are cleared by Customs with the authorization "Declaration on temporary export of hunting or sporting guns", goods for use by the European Space Agency (ESA), goods, services and technologies for use on the Norwegian part of the Continental Shelf, or on board Norwegian ships under a Norwegian flag, and Norwegian aircraft during international flights. Types of Licenses: for items on List I an individual license (authorizing a specified shipment to a single, specified recipient) will be required. For items on List II a general license may be available, usually when exports are to recipients in Argentina, Australia, Canada, Hungary, Iceland, Japan, New Zealand, Switzerland or the United States or when the recipient is located in a European Union member state. A general license will be valid for 3 years.

\section{POLAND}

Legislation: Decision of Council of Ministers Regulation of 14 September 1999 "On prohibition and limitation in foreign special trade"; Law of 29 November 2000 concerning international trade in goods, technologies and services of strategic significance for state security and maintenance of international peace and security, and amending selected laws. Licensing Authority: Ministry of Economy, Department of Export Control. Consultation Procedures: Ministry of Foreign Affairs, the Ministry of Defense, the Ministry of Internal Affairs and Administration, the State Protection Office. End User Requirements: it is necessary to provide an end-user certificate for each export contract with a proper non-re-export clause to avoid risk of transfers to states subject to UN embargoes, EU restrictions or accused of supporting terrorism (as a minimum a ban on the reexport of commodities to the states which are subject to UN embargoes). Licensing Negotiations: the Ministry of Economy should be informed about negotiations and intent to offer controlled items but no license is required. Licensing Exemptions: export of arms always requires a permit. Revocation Licenses: export permits may be canceled in cases where a company breaks the law and when the transfer causes threat to the national interest, state security or national foreign policy goals. Types of Licenses: general licenses are used for export controls applied to dual-use goods. For conventional arms an individual license is used. 
Individual license: always required (including by those companies that do not require a general license) to carry out a particular transaction (issued on a case-by-case basis). These may be of four kinds: to enter into negotiations and provide an offer; to carry out export and/or import; to carry out re-export; to carry out transit.

\section{RUSSIA}

Legislation: Federal law of the Russian Federation on Military-Technical Cooperation of the Russian Federation With Foreign States, adopted by the State Duma on 3 July 1998 and approved by the Federation Council on 9 July 1998; Russian Federation Presidential Decree No 1953, "to form the Russian Federation Committee for MilitaryTechnical Cooperation with Foreign States", 1 December 2000. Licensing Authority: Committee for Military-Technical Cooperation With Foreign States. Consultation Procedures: Ministry of Foreign Affairs, Ministry of Defense, Ministry of Finance, Ministry of Economics, State Customs Service, Foreign Intelligence Service, Federal Security Service. End User Requirements: federal executive institutions of the Russian Federation shall supervise deliveries of military products intended for transfer to foreign clients. Executive institutions monitor the development, manufacture and delivery of military products according to the procedure determined by the Government of the Russian Federation. Licensing Negotiations: marketing and contract negotiations require authorization from the Committee for Military-Technical Cooperation With Foreign States. Revocation Licenses: organizations and enterprises require authorization to take part in military-technical cooperation with foreign states. This authorization is subject to review by the Committee for Military-Technical Cooperation With Foreign States and can be withdrawn by that Committee.

\section{SPAIN}

Legislation: Royal Decree No. 491/1998 of 12 March 1998. Licensing Authority: Inter-Ministerial Regulatory Board on Foreign Trade in Defense or Dual-Use Material (JIMDDU) within the Ministry of Economy and Taxes. The Under-Director-General for Foreign Trade of Defense and Dual-Use Material at the Ministry of Economy and Taxes provides a secretariat for the Board. JIMDDU is chaired by the Secretary of State for Trade, Tourism and Small and Medium Enterprises. The Deputy Chair is Under-Secretary in the Ministry of Foreign Affairs. Consultation Procedures: 
represented on the Inter-Ministerial Regulatory Board on Foreign Trade in Defense or Dual-Use Material are the Ministries of Trade, Tourism and Small and Medium Enterprises, the Ministry of Defense, the Ministry of Domestic Affairs, the Ministry of Industry and Energy. End User Requirements: an end-user certificate issued by a government agency in the importing state is required for exports of war material. For other materials that are for military use an end-user certificate may be issued by a company. If there are doubts about the final destination additional controls may be applied. Licensing Negotiations: no authorization is needed to negotiate or sign a contract. Licensing Exemptions: none. Revocation Licenses: licenses can be revoked: when the export might threaten peace or stability on a regional or global level; when the export contravenes Spain's international commitments; when the export threatens Spain's national defense or foreign policy interests. Types of Licenses: Individual licenses valid for 6 months are used for war material exports.

\section{SWEDEN}

Legislation: Military Equipment Act (1992); Military Equipment Ordinance (1992). Licensing Authority: The National Inspectorate of Strategic Products (ISP), which is obliged to submit cases of principal significance or cases which are otherwise important to the Government. Consultation Procedures: Ministry of Foreign Affairs, Ministry of Defense. End User Requirements: in principle required for all exports. Licensing Exemptions: a private person may take small arms and ammunition out of the country for his personal use if entitled under the Weapons Act (1973). Revocation Licenses: a license may be revoked. Types of Licenses: only one type of license used.

\section{SWITZERLAND}

Legislation: Article 41 and article 64 of the Federal Constitution of the Swiss Confederation of 29 May 1874 (as amended); Federal Law on War Material of 13 December 1996; Federal Law on the control of dual use goods and specific military goods of 13 December 1996; Ordinance on the exportation, importation, and transit of dual use goods and specific military goods of 25 June 1997; Ordinance on War Material of 25 February 1998. Licensing Authority: designated by the Federal Council, the Swiss Federal Office for Foreign Economic Affairs (OFAEE, Office FÈdÈral des Affaires 
Economiques ExtÈrieures) is authorized to issue licenses (art. 13 of ordinance of 25 February 1998). Consultation Procedures: procedures are established in art. 14 of ordinance of 25 February 1998 and are as follows: 1the OFAEE issues authorizations for further marketing authorizations in tandem with the Federal Department of Foreign Affairs. Moreover, the OFAEE consults the relevant branch of the Federal Department of Defense, of Civil Protection, and Sports (DDPS) if political security or armament interests are in question. It consults the Federal Office of Energy (OFEN) if nuclear issues are present; 3) the relevant services decide whether requests are of major importance regarding foreign or security policy and thus must be submitted to the Federal Council; 4) if the relevant services cannot agree on the proper treatment of the requests the latter are submitted the Federal Council; 5) in cases of minor importance or if there are precedents, the relevant authorities can authorize the OFAEE to take decisions. End User Requirements: Art. 18 of law of 13 December stipulates that export authorizations are usually only issued for goods destined to foreign governments or companies working for foreign governments, and a declaration that the goods will not be reexported. The clause may not be required for parts destined to be integrated (and are integrated) and then exported or for anonymous parts of negligible value. Licensing Negotiations: initial authorization required for commercial activity including the process of offering, acquiring, and transferring. Brokerage and transfer of intellectual property also subject to authorization (art. 6,9 , and 20 of law of 13 December 1996). Licensing Exemptions: the licensing scheme is not applicable to armament companies when their activities are related to acquisition of material for the Swiss army (art. 4 of law of 13 December). Temporary export of weapons by persons participating in firing competitions or training are exempt (art 9 of ordinance of 25 February 1998). Revocation Licenses: licenses can be revoked or suspended in exceptional circumstances (art.19 of law of 13 December 1998). Types of Licenses: Six types of authorization: manufacture, brokerage, importation, exportation, transit and intellectual property (art. 12 of law of 13 December 1996). Import, export, and transit licenses last 12 months and can be extended by six months (art. 15 of ordinance of 25 February 1998).

\section{UK}

Legislation: Export of Goods (Control) Order 1994 (as amended). Export Control Act 2002. Licensing Authority: Department of Trade and Industry. Consultation 
Procedures: Foreign and Commonwealth Office, Ministry of Defense, Department for International Development. End User Requirements: provision of end-user certificate including obligation not to re-export needed. Licensing Negotiations: no authorization needed for negotiating contracts unless classified information has to be released. Licensing Exemptions: government to government transfers; companies acting on behalf of their governments: exemption on the grounds of Crown Status; government to government collaborative projects. Revocation Licenses: the Secretary of State for Trade and Industry may revoke export licenses at any time and for any reason.

\section{USA}

Legislation: Arms Export Control Act of 1976 (as amended). Licensing Authority: Department of State. Consultation Procedures: The Department of State seeks the views of the Department of Defense and other relevant specialist agencies (such as the National Aeronautics and Space Agency (NASA)) in around 30\% of license cases. End User Requirements: a Non-Transfer and Use Certificate is required as a condition to the approval of any license or agreement that relates to significant military equipment, classified articles or classified technical data. Written approval of the Office of Defense Trade Controls must be obtained before reselling, transferring, transshipping or disposing of a defense article to any end user, end use or destination other than that stated in the export license. Licensing Negotiations: a marketing license is required for contacts with potential customers if information or technical data covered by the US Munitions List is revealed in the course of the contact. Revocation Licenses: licenses can be revoked at the discretion of the President and the Secretary of State under a wide range of circumstances. Types of Licenses: there are 4 types of document that can authorize exports of controlled items: 1) export licenses: Documents that permit the temporary or permanent export of items on the US Munitions List; 2) technical assistance agreements: a contract for the delivery of a defense service or disclosure of technical data; 3) manufacturing licenses: a document whereby a US legal person grants a foreign person authorization to manufacture defense articles abroad; 4) distribution agreements: a contract to establish a warehouse or distribution point abroad for defense articles exported from the US for subsequent distribution to entities in an approved sales territory. 


\section{UKRAINE}

Legislation: Law on State Control of international Transfers of Goods Designated for Military Purposes and Dual-Use Goods, 20 February, 2003; Decree no. 117/98 of the President of Ukraine, 13 February 1998; Decree no. 422/99 of the President of Ukraine, 21 April 1999; Decree no. 423/97 of the President of Ukraine, 13 May 1997; Provisions approved by Decree no. 1005 of the Cabinet of Ministers of Ukraine, 22 June 1996; Provisions approved by Decree no. 125 of the Cabinet of Ministers of Ukraine, 4 February 1997 with changes according to Decree no. 1042 by the Cabinet of Ministers 15 June 1999; Provisions approved by Decree no. 1358 by the Cabinet of Ministers of Ukraine, 8 December 1997; Decree no. 1228 of the Cabinet of Ministers of Ukraine, 12 July 1999;Decree no. 473 of the Cabinet of Ministers of Ukraine, 10 March 2000. Licensing Authority: State Service on Export Control. Consultation Procedures: the Commission on Export Control Policy and Military and Technical Cooperation with Foreign Countries, which is now under the authority of the Presidential Administration. End User Requirements: decisions on a case-by-case basis. Licensing Negotiations: an exporter requires permission from the State Service on Export Control to begin contract negotiations with a foreign customer. Licensing Exemptions: none. Revocation Licenses: licenses can be revoked or suspended if: there are reasons to believe that the end-use of the items run counter to the information contained in the license application; the exporter becomes bankrupt or ceases to exist; the terms of the contract with the foreign partner that was the basis for the license application was altered after the license was issued; or if the transfer violates Ukraine's international obligations. Types of Licenses: general and individual licenses are available. 


\section{Bibliography}

Amnesty International, IANSA and Oxfam (2006): "UN Arms Embargoes: An Overview of the Last 10 Years", Control Arms Briefing Notes.

Alesina, A. and D. Dollar (2000): "Who Gives Foreign Aid to Whom and Why?", Journal of Economic Growth, 5 (1), 33-63.

Anderson, JE. and V. Wincoop (2003): "Gravity with Gravitas: a Solution to the Border Puzzle", American Economic Review, 93, 1, 170-192 (23).

Beck, T., G. Clarke, A. Groff, P. Keefer, and P. Walsh (2001): "New tools in comparative political economy: The Database of Political Institutions", World Bank Economic Review 15 (1), 165-176.

Bergstrand, J. (1985): "The Gravity Equation in International Trade: Some Microeconomic Foundations and Empirical Evidence." The Review of Economics and Statistics, 67 (3), 474-481.

Blanton, S.L. (2000): "Promoting Human Rights and Democracy in the Developing World: U.S. Rhetoric vs. U.S. Arms Exports", American Journal of Political Science, 44 (1), 123-131.

Brauer, J. (2000): "Potential and Actual Arms Production: Implications for the Arms Trade Debate", Defense and Peace Economics, 11, 5.

Brzoska, M. (1982): "Arms Transfer Data Sources", Journal of Conflict Resolution, $26,1,77-108$.

Dunne J.P., M. Garcia Alonso, P. Levine and R.P. Smith (2003): "Concentration in the International Arms Industry", Discussion Paper n. 301, University of West England.

Egger, P. (2000): "A Note on the Proper Econometric Specification of the Gravity Equation", Economic Letters, 66, 25-31.

Frankel, J.A. and D. Romer (1999): "Does Trade Cause Growth?", American Economic Review, 89 (3), 379-399.

Gleditsch, K. (2002): "Expanded Trade and GDP Data", Journal of Conflict Resolution, 46, 712-24. 
Gleditsch, K. and M. Ward (2001): "Measuring Space: A Minimum Distance Database", Journal of Peace Research, 38, 749-68.

Glick, R. and A. K. Rose (2002): "Does A Currency Union Affect Trade? The Time-Series Evidence", European Economic Review, 46 (6), 1125-1151.

Hagelin, B. and S. Wezeman (2005): "Sources and Methods for Arms Transfers Data", SIPRI Yearbook 2005, Appendix 10.C, Oxford University Press.

Hartley, K. and T. Sandler (1995): "Economics of Arms Trade", Handbook of Defense Economics, Elsevier, edition 1, volume 1.

Huntington, S. (1991): "The Third Wave: Democratization in the Late Twentieth Century", University of Oklahoma Press.

IANSA, Oxfam, and Safeworld (2007): "Africa's Missing Billions", Control Arms Briefing Paper.

Kollias, C. and K. Sirakoulis (2002): "Arms Racing and the Costs of Arms Imports: A Stochastic Model", Defense and Peace Economics, 13, 2, 137-143.

Krause, K. (1991): "Military Statecraft: Power and Influence in Soviet and American Arms Transfer Relationship", International Studies Quarterly, 35 (3), 313-336.

Levine, P. and R Smith (1995): "The Arms Trade and Arms Control", Economic Journal, 105, 471-484.

Levine, P. and R. Smith (1997): "The Arms Trade and the Stability of Regional Arms Races", Journal of Economic Dynamics and Control, 21, 2, 631-654.

Levine, P. and R. Smith (2000): "The Arms Trade Game: from Laissez Faire to a Common Defense Policy", Oxford Economic Papers, 52, 2, 357-380.

Martin, S. (1999): "The Subsidy Savings from Reducing UK Arms Exports", Journal of Economic Studies, 26, 1, 15-37.

Martin, S., K. Hartley and B. Stafford (1999): "The Economic Impact of Restriction UK Arms Exports", International Journal of Social Economics, 26, 6, 779-802.

Miller, K. and C. Brooks (2001): "Export Controls in the Framework Agreement Countries", British American Security Information Council Research Report, 2001-1. 
Papaioannou E. and G. Siourounis (2008) : "Democratization and Growth", Economic Journal, 118(532), 1520-1551.

Pearson, F.S. (1989): "The Correlates of Arms Importation", Journal of Peace Research, 26, 2, 153-163.

Peleg, I. (1977): "Arms Supply to the Third World: Models and Explanations", The Journal of Modern African Studies, 15, 1, 91-103.

Skons, E. (2000): "Trends in Military Expenditure and Arms Transfers", UNU Working Paper.

Smith, R. and A. Tasiran (2005): "The Demand for Arms Imports", Journal of Peace Research, 42, 167-181.

Smith, R., A. Humm and J. Fontanel (1985): "The Economics of Exporting Arms", Journal of Peace Research, 2, 3, 239-247.

Summary, R.M. (1989): "A Political-Economic Model of US Bilateral Trade", The Review of Economics and Statistics, 71,1, 179-182. 